\title{
Lung Mixed Squamous Cell and Glandular Papilloma
}

National Cancer Institute

\section{Source}

National Cancer Institute. Lung Mixed Squamous Cell and Glandular Papilloma. NCI

Thesaurus. Code C45602.

An exceedingly rare benign endobronchial neoplasm characterized by the presence of fibrovascular cores which are lined by both squamous and glandular epithelium. Patients present with obstructive symptoms. Complete resection is curative. 